non-fatal bleeding was reported in $4.1 \%$.

The higher complication rate in our study could be due to other criteria for evaluating the complication rate, to complications related at least partly to the frequent use of arteriography, to the bad general condition of most of our patients on admission, or to the use of a rather high initial dose of streptokinase.

Since the introduction of Fogarty's catheter (Fogarty et al., 1963) the possibilities of vascular surgery have been extended, and this method represents an important alternative for the treatment of patients having the condition under study. An attempt has therefore been made to review published work with the purpose of comparing streptokinase treatment, modern medical therapy, and vascular surgery in patients with recent thromboembolic occlusions of the limb arteries (Amery, 1969).

Streptokinase was kindly supplied by Kabi AB, Stockholm.

\section{REFERENCES}

Amery, A. (1969). Activation of the Human Plasma Fibrinolytic System by Streptokinase, Thesis, Acco-Louvain, Belgium.

Amery, A., Maes, H., Vermylen, J., and Verstraete, M. (1963). Thrombosis et Diathesis Haemorrhagica, 9, 175 .

Amery, A., Roeber, G., Vermeulen, H. J., and Verstraete, M. (1969). Acta Medica Scandinavica, Suppl. No. 505

Cotton, L. T., Flute, P. T., and Tsapogas, M. J. C. (1962). Lancet, 2, 1081.

Fletcher, A. P., Alkjaersig, N., and Sherry, S. (1959). Journal of Clinical Investigation, 38, 1096 .
Fogarty, T. J., Cranley, J. J., Krause, R. J., Strasser, E. S., and Hafner, C. D. (1963). Surgery, Gynecology and Obstetrics, 116, 241 .

Gross, R., Hartl, W., Kloss, G., and Rahn, B. (1960). Deutsche medizinische Wochenschrift, 85, 2129.

Haan, D., and Tilsner, U. (1965). Münchener medizinische Wochenschrift, 107,638 .

Hess, H. (1967). Arterielle Embolien und Thrombosen. Stuttgart, Schattauer. Hiemeyer, V., Rasche, H., and Diehl, K. (1969). Klinische Wochenschrift, 47,371 .

Kahn, P., Stacher, A., and Deutsch, E. (1961). Wiener klinische Wochenschrift, 73, 677 .

McNicol, G. P., Reid, W., Bain, W. H., and Douglas, A. S. (1963). British Medical fournal, 1, 1508 .

Marchal, G., et al. (1964). Archives des Maladies du Coeur et des Vaisseaux, $57,753$.

Nilsson, I. M., and Olow, B. (1962). Acta Chirurgica Scardinavica, 123, 247.

Poliwoda, H., Alexander, K., Buhl, V., Holstein, D., and Wagner, H. H. (1969). New England fournal of Medicine, 280, 689 .

Remy, D., and Gebauer, D. (1966) Medizinische Klinik, 61, 220.

Salmon, J., Lambert, P. H., and Delvigne, J. (1963). Acta Cardiologica, 18, 254.

Schmutzler, R. (1963). Helvetica Medica Acta, 30, 608.

Schmutzler, R. (1968). Angiologica, 5, 119

Schoop, W., Martin, M., and Zeitler, E. (1968). Deutsche medizinische Wochenschrif:, 93, 2321.

Verstraete, M., Amery, A., and Vermylen, J. (1963). British Medical fournal, 1,1499 .

Verstraete, M., Vermylen, J., Amery, A., and Vermylen, C. (1966). British Medical fournal, 1, 454 .

Verstraete, M., Vermylen, J., De Vreker, R., Amery, A., and Vermylen, C. (1964). Scandinavican fournal of Clinical and Laboratory Investigation, 16, Suppl. No. 78, p. 15.

Winckelmann, G., Hiemeyer, V., Weissleder, H., and Schoop, W. (1963). Deutsche medizinische Wochenschrift, 88, 2331.

\title{
Folic Acid in Folate-deficient Patients with Epilepsy
}

\author{
RICHARD H. E. GRANT,* M.B., B.S., D.C.H. ; OLGA P. R. STORES, $†$ м.в., СH.в.
}

\begin{abstract}
ummary: A double-blind trial using folic acid $15 \mathrm{mg}$. daily and identical placebo was carried out in 51 epileptic patients having a serum folate level below $3.6 \mathrm{ng} . /$ $\mathrm{ml}$. Treatment was for a minimum of six months and in 41 patients was for more than one year. There were no significant changes in the frequency of seizures, behaviour, ind personality, or in a number of cognitive functions.
\end{abstract}

\section{Introduction}

Treatment with certain anticonvulsant drugs, especially phenytoin, produces folate deficiency in a high proportion of patients, estimates varying from about 30 to $80 \%$ (Klipstein, 1964; Reynolds et al., 1966a, 1966b). Megaloblastic anaemia is the most obvious manifestation of this deficiency but it is rare, though a megaloblastic bone marrow may be found in nearly $40 \%$ of treated epileptic patients (Reynolds et al., 1966b) and macrocytosis in the peripheral blood in between 11 and 53\% (Reynolds, 1968). Phenytoin inhibits folate absorption from folate polyglutamates, a major component of food folate, and possibly folate deficiency is at least partly due to inhibition of intestinal absorption of folates in the diet (Hoffbrand and Necheles, 1968; Rosenberg et al., 1968).

The clinical consequences of drug-induced folate deficiency have been described by Reynolds (1968, 1970). These include apathy and retardation, loss of concentration and self-confidence, schizophrenic-like psychoses, dementia, and possibly cerebellar or spinal cord damage. If the folate deficiency is corrected by treatment with folic acid the mental state may improve, but at the same time the frequency or severity of

* Director, David Lewis Colony, Alderley Edge, Cheshire.

t Registrar, David Lewis Colony, Alderley Edge, Cheshire. fits has been reported to increase in a significant proportion of patients. Reynolds (1967) studied 26 chronic epileptic patients with folic acid deficiency. Folic acid improved the mental state, but the frequency or severity of fits was increased, necessitating cessation of treatment in ninc patients. Other reports include the case of a man of 43 with megaloblastic anaemia due to phenobarbitone in whom administration of folic aicd rapidly precipitated status epilepticus on two occasions (Chanarin et al., 1960) and a case reported by Wells (1968) in which the patient died in uncontrolled status epilepticus. Dennis and Taylor (1969) described their experience with 5-mg. tablets of folic acid in children with epilepsy as "alarming" but gave no clinical details. Lanzkowsky et al. (1969) studied an 18-year-old girl with an isolated defect of folic acid absorption associated with mental retardation and cerebral calcification who developed epilepsy. They reported that fits decreased in frequency during folatc depletion and increased on folic acid administration, but the degree of change was not stated.

Our clinical impression and that of our colleague, Dr. Neil Gordon (1968), was that folic acid had little observable effect on either the incidence of seizures or behavioural aspects. This impression was gained both from patients and from children attending the outpatient department. It was therefore decided to carry out a controlled clinical trial to assess a number of values in our patients.

\section{Methods}

Preliminary screening of serum folic acid levels in inpatients was carried out, and 51 patients whose serum folate level was less than $3.6 \mathrm{ng} . / \mathrm{ml}$. were selected for study, this level being the lower limit for the laboratory concerned. Of 
these 26 were men and 25 women, ranging in age from 16 to 65 (mean 33.4) years. The patients were allocated at random to treatment with folic acid $5 \mathrm{mg}$. three times a day or an identical placebo tablet $5 \mathrm{mg}$. three times a day; the randomization took into account the frequency of seizures so that their distribution was about equal in the two groups, as was the type of epilepsy. Treatment was double-blind to all concerned within the trial. All the patients were observed for 26 weeks before treatment and for at least 26 weeks after starting treatment. In 41 of the patients the period of observation was over one year. Anticonvulsant therapy remained static throughout the trial unless a change was essential on clinical grounds. Patients with serum phenytoin levels in excess of 25 $\mu \mathrm{g} . / \mathrm{ml}$. were either excluded from the trial or stabilized beforehand (Stensrud and Palmer, 1964).

Observations were made on the following criteria:

(1) Seizures.-These were recorded in the following categories: A, grand mal with definite tonic/clonic convulsions; B, modified grand mal in which the tonic or clonic phase may be very short; C, petit mal; D, akinetic ("drop") attacks; E, focal attacks, either motor or sensory; F, psychomotor attacks; and G, other attacks not conveniently falling into any of the categories A-F and which are described individually. This classification is used for all patients at the colony and daily records are maintained routinely. All staff have been instructed in the classification. The major difficulty has been found in classifying psychomotor attacks, and our type $\mathrm{F}$ inevitably contains a rather heterogeneous group of seizures. Nevertheless, we believe this classification combines a relatively comprehensive list of seizures with reasonable simplicity for staff, most of whom are not trained nurses.

(2) Cognitive Functions and Memory Tests.-The following tests were done on each patient before and after 26 weeks' treatment: (1) Wechsler adult intelligence scale (W.A.I.S.) (2) Raven's standard progressive matrices: the test was carried out in the standard way, but in addition to the total score a record was kept of the score attained 15 minutes after starting the test; if folic acid is effective in increasing speed of thought and concentration the score at 15 minutes might increase after treatment though the full score might not. (3) Sorting random letters: the patient was presented with a series of 156 randomized capital letters in six rows of 26 and instructed to cross out all the letter "I"s; the test was timed with a stop-watch and three trials were given, each with a separate randomization; the mean time in seconds was recorded; this test was used as an indication of speed of thought and action. (4) Rey-Davis peg board test (Williams, 1968). (5) Delayed recall of pictures (Williams, 1968). (6) Counting numbers: the subject is asked to count aloud from one onwards as fast as he can; the score is the number reached in 15 seconds, timed by stop-watch.

(3) Personality and Behaviour.-(1) Eysenck-Withers personality inventory: though normally the subject completes this inventory himself, because many of our patients have limited reading ability we asked the appropriate questions and marked the inventory ourselves. (2) Behaviour rating scale (Pritchard, 1963): we recognize the considerable difficulty in standardizing observations of behaviour, but felt it was desirable to use some scale which could be used by nursing staff. Though Pritchard designed his scale for measuring changes in behaviour in children, we felt that many of the target symptoms were important in our patients and included those which might be expected to improve with folic acid treatment. The scale was modified slightly, the unipolar items being omitted. Nine bipolar items were used, the normal being 0 . with extremes of -3 and +3 . Each of the values on the scale was scored by the senior nursing staff on the house in which the patient lived and to whom he was best known. Observations were made before treatment and monthly throughout the trial.

\section{Results}

Details of the 51 patients are given in Table I: 25 (mean serum folate $1.4 \mathrm{ng} . / \mathrm{ml}$.) received folic acid and 26 received placebo tablets (mean serum folate $1.11 \mathrm{ng} . / \mathrm{ml}$.). Of the patients in the folic acid-treated group, electroencephalograms showed that 12 had centrencephalic epilepsy, 5 focal epilepsy, 2 non-specific changes, and the remaining 6 had not had recent E.E.G.s. In the placebo-treated group, 10 had centren- cephalic and 7 focal epilepsy, 3 non-specific changes, and 5 had not had recent E.E.G.s.

Three patients were withdrawn from the trial. One (Case 3), a 45-year-old woman receiving folic acid, was withdrawn because she was transferred to other accommodation. Another (Case 16), a 19-year-old man, went home for a four-week summer holiday, during which time he had frequent attacks, probably akinetic (type D). His mother stopped the folic acid tablets. No change in anticonvulsant treatment was made. On his return to the colony the attacks immediately subsided to the previous frequency. On further questioning it appeared that he often had more frequent attacks at home, possibly related to complete lack of occupation, but it was decided not to begin folic acid again. The third withdrawal (Case 32) was a 16-year-old youth taking placebo tablets who discharged himself against advice before completion of the trial.

Attacks.-The actual number of attacks recorded in the 26 weeks before and after treatment in each patient are shown in Table I. None of the patients had focal (type E) attacks, and it was impractical to analyse the petit mal (type C) attacks numerically. No patient was observed to have a clinically significant increase in the frequency of petit mal attacks. Table II gives the number of patients showing an incrcase/decrease/no change in the frequency of grand mal (A), modified grand mal (B), akinetic (D), and psychomotor (F) attacks, and also for all grand mal attacks $(A+B)$ during the first 26 weeks of treatment, the actual figures being represented graphically in Figs. 1 and 2 . In the folic-acidtreated group 10 patients showed an increase, 11 a decrease,

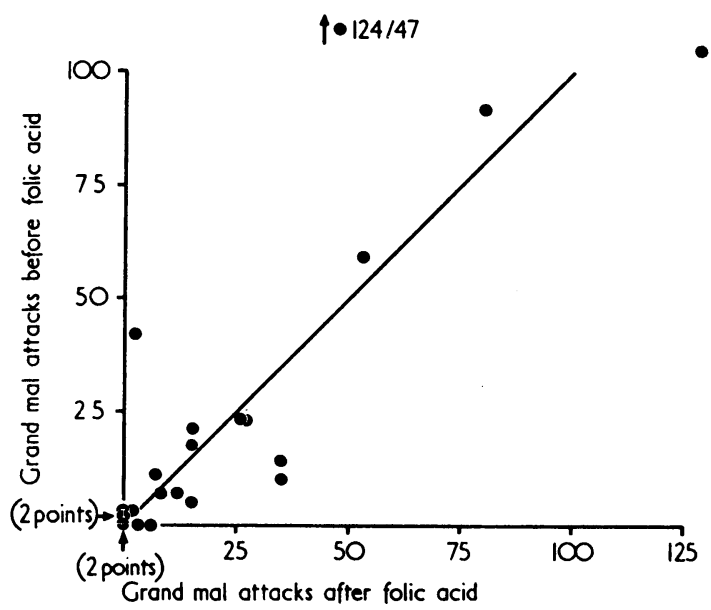

FIG. 1.-Incidence of grand mal attacks before and after 26 weeks' treatment with folic acid.

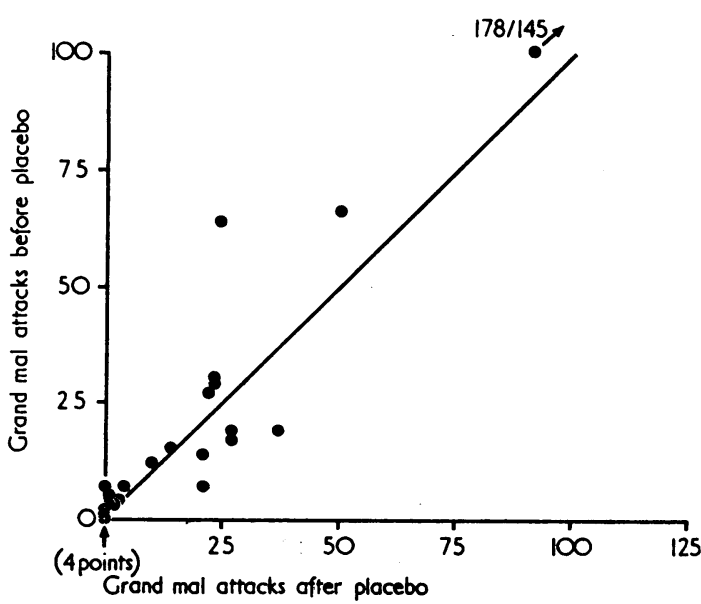

FIG. 2.-Incidence of grand mal attacks before and after 26 weeks' treatment with placebo. 
TABLE I.-Details of Patients with Seizure Frequency Before and After Treatment

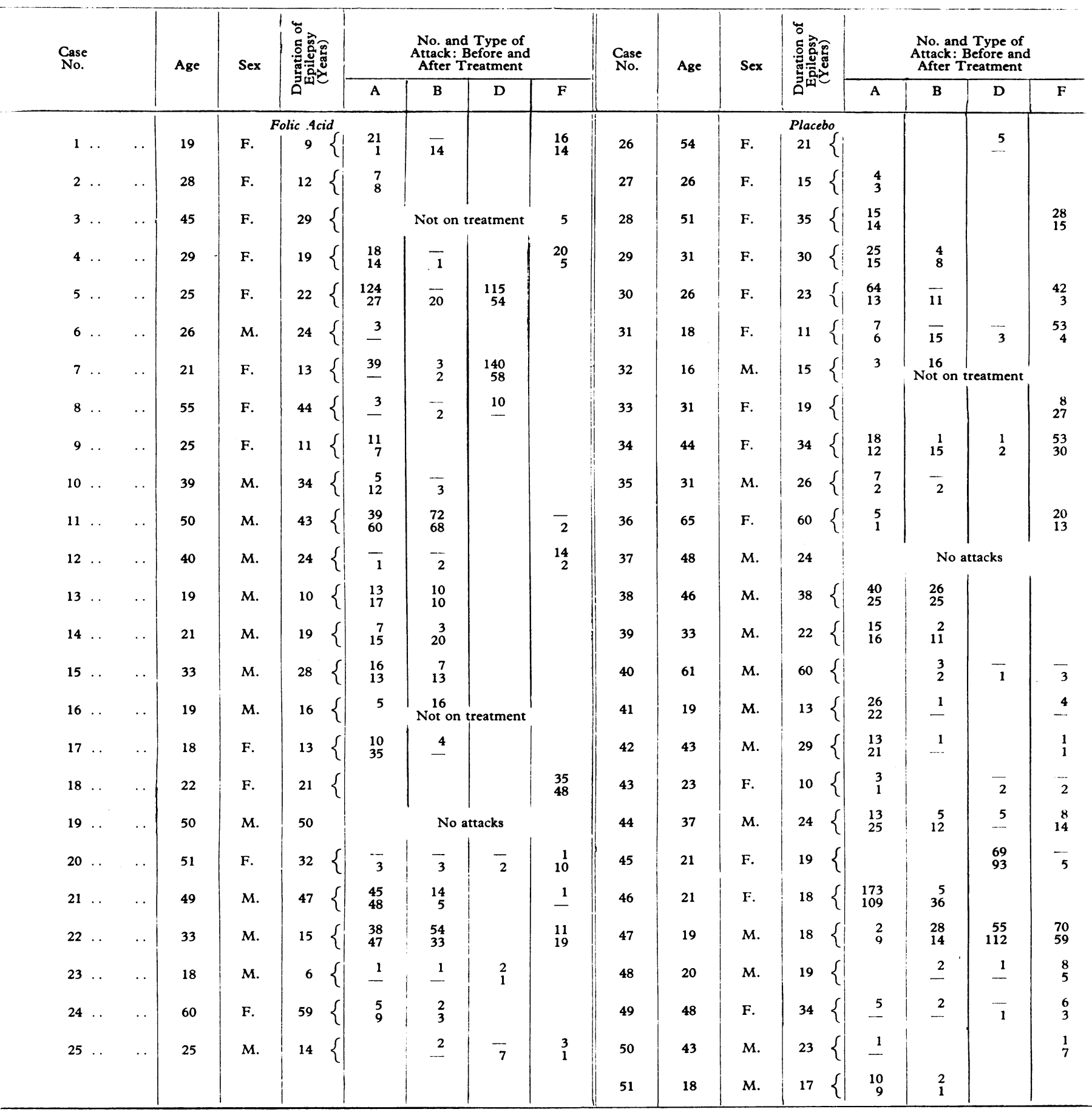

and 2 no change in frequency of major fits. In the placebo group the corresponding figures were 5,16 , and 4 . The difference is not statistically significant at $5 \%$. The results for the period 27-52 weeks' treatment compared with the control period in the 41 patients who have been observed for over one year are also given in Table II. The mean changes in grand mal attacks are shown in Table III, together with the differences in these means and the value for Student's $t$ test. There is no significant difference between folic-acid-treated and placebo-treated groups.

Cognitive Functions. - The mean changes in all cognitive functions are shown in Table III. There were no statistically significant differences in these values. In the random letters test the placebo-treated group showed a mean reduction of 4.28 seconds in the time taken to cross out the letters, and in the folic-acid-treated group there was a mean increase of 3.05 seconds. This difference approaches but does not reach statistical significance $(t=1.96,0.1>\mathrm{P}>0.05)$. Though we did not expect any major changes in "general intelligence," we felt that some of the timed items of the W.A.I.S. and the immediate recall test (digit span) might show an improvement. Comparison of the number of patients showing improvement or deterioration in these items is shown in Table IV, together with the difference in the mean changes, the latter being very close to zero. None of these changes is significant.

Personality and Behaviour.-The mean changes in the three scales of the Eysenck-Withers personality inventory are shown in Table III. Patients treated with folic acid showed a mean increase of 1.32 on the neuroticism scale, whereas the placebo-treated patients decreased by a mean of 1.24. This 
TABLE II.-Number of Patients Showing Increase/Decrease/No Change in Fit Frequency after 26 Weeks' Treatment and for 27-52 Weeks' Treatment for Major Seizures

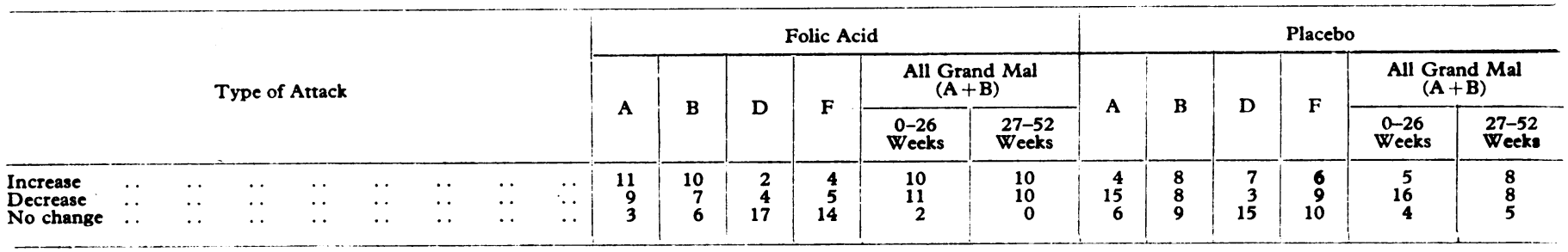

TABLE III.-Mean Changes of All Values

\begin{tabular}{|c|c|c|c|c|c|c|c|c|c|c|c|c|c|c|}
\hline & \multicolumn{2}{|c|}{ Grand Mal Attacks } & \multicolumn{3}{|c|}{ w.A.I.S. } & \multicolumn{2}{|c|}{ Raven's Matrices } & \multirow{2}{*}{ 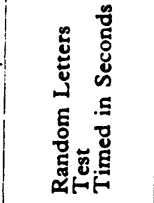 } & \multirow{2}{*}{ 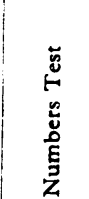 } & \multirow{2}{*}{ 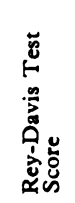 } & \multirow{2}{*}{ 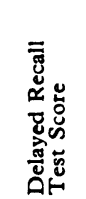 } & \multicolumn{3}{|c|}{$\begin{array}{l}\text { Eysenck-Withers } \\
\text { Personality Inventory }\end{array}$} \\
\hline & $\begin{array}{c}0-26 \\
\text { Weeks }\end{array}$ & $\begin{array}{c}27-52 \\
\text { Weeks } \\
\text { (41 Patients) }\end{array}$ & $\begin{array}{l}\mathbf{Y} \\
\text { IQ }\end{array}$ & $\begin{array}{l}\mathbf{P} . \\
\mathbf{I}\end{array}$ & IQ.S. & $\begin{array}{l}\text { 15- } \\
\text { Minute } \\
\text { Score }\end{array}$ & $\begin{array}{l}\text { Full } \\
\text { Score }\end{array}$ & & & & & $\mathbf{N}$ & $\mathrm{E}$ & L \\
\hline 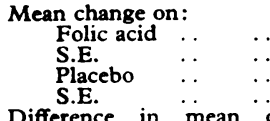 & $\begin{array}{l}-2.65 \\
4.26 \\
-2.92 \\
2.48\end{array}$ & $\begin{array}{r}-3.75 \\
5.46 \\
-7.0 \\
5.31\end{array}$ & $\begin{array}{l}1.96 \\
0.64 \\
0.44 \\
0.78\end{array}$ & $\begin{array}{l}1.09 \\
1.61 \\
2.08 \\
0.78\end{array}$ & $\begin{array}{l}1.64 \\
1.07 \\
0.92 \\
0.76\end{array}$ & $\begin{array}{l}-0.09 \\
1.27 \\
0.24 \\
0.90\end{array}$ & $\begin{array}{l}2.32 \\
1.05 \\
1.18 \\
0.92\end{array}$ & $\begin{array}{r}3.05 \\
3.09 \\
-4.28 \\
2.12\end{array}$ & $\begin{array}{l}2.32 \\
0 \cdot 73 \\
4 \cdot 04 \\
1 \cdot 15\end{array}$ & $\begin{array}{l}-0.64 \\
-0.54 \\
-1.00 \\
0.48\end{array}$ & $\mid \begin{array}{r}-0.95 \\
1.93 \\
0.04 \\
2.71\end{array}$ & $\begin{array}{r}1.32 \\
0.55 \\
-1.24 \\
0.73\end{array}$ & $\begin{array}{r}-0.27 \\
0.72 \\
0.52 \\
0.94\end{array}$ & $\begin{array}{l}0.64 \\
0.42 \\
0.76 \\
0.44\end{array}$ \\
\hline $\begin{array}{l}\text { F.A-P. } \quad . \\
t \text { Significance }\end{array}$ & $\begin{array}{l}0.27 \\
0.05 \\
\text { N.S. } \\
\text { N.S. }\end{array}$ & $\begin{array}{l}3.25 \\
\text { 0.43 } \\
\text { N.S. }\end{array}$ & $\begin{array}{l}1.52 \\
1.5 \\
\text { N.S. }\end{array}$ & 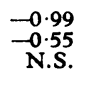 & $\begin{array}{l}0.72 \\
0.54 \\
\text { N.S. }\end{array}$ & $\begin{aligned} &-0.33 \\
&-0.21 \\
& \text { N.S. }\end{aligned}$ & $\begin{array}{l}1.14 \\
0.72 \\
\text { N.S. }\end{array}$ & $\begin{array}{c}7.33 \\
1.96 \\
0.1>P>0.05\end{array}$ & $\begin{array}{l}-1.72 \\
-1.26 \\
\text { N.S. }\end{array}$ & $\begin{array}{l}0.36 \\
0.50 \\
\text { N.S. }\end{array}$ & $\begin{array}{l}-0.99 \\
--0.30 \\
\text { N.S. }\end{array}$ & $\begin{array}{l}2.56 \\
2.8 \\
P<0.05\end{array}$ & $\begin{aligned}-0.79 \\
-0.67 \\
\text { N.S. }\end{aligned}$ & $\begin{array}{l}-0.12 \\
-0.20 \\
\text { N.S. }\end{array}$ \\
\hline
\end{tabular}

S.E. $=$ Standard error of mean change.
N.S. $=$ Not significant.
V.IQ = Verbal I.Q P.IQ $=$ Performance $I . Q$.
F.S.IQ $=$ Full scale I.Q.
$\mathbf{N}=$ Score on neuroticism scale.
$\mathrm{E}=$ Score on extraversion scalc.

$\mathrm{E}=$ Score on
$\mathrm{L}=$ Lie scale.
TABLE V.-Number of Patients Showing Improvement/Deterioration/No Change in the 9 Items of the Behaviour Rating Scale at the End of 26 Weeks' Treatment

\begin{tabular}{|c|c|c|c|c|c|c|c|}
\hline \multirow{2}{*}{\multicolumn{2}{|c|}{ Item }} & \multicolumn{2}{|c|}{ Improved } & \multicolumn{2}{|c|}{ Deteriorated } & \multicolumn{2}{|c|}{$\begin{array}{c}\text { No } \\
\text { change }\end{array}$} \\
\hline & & F.A. & P. & F.A. & P. & F.A. & P. \\
\hline 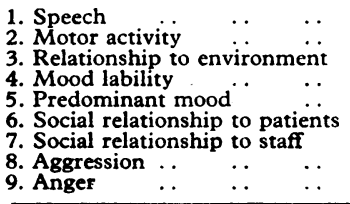 & $\begin{array}{l}\cdots \\
\cdots \\
\cdots \\
\cdots \\
\cdots \\
\cdots \\
\cdots\end{array}$ & $\begin{array}{r}4 \\
9 \\
1 \\
7 \\
7 \\
6 \\
6 \\
9 \\
11\end{array}$ & $\begin{array}{r}6 \\
7 \\
5 \\
12 \\
5 \\
6 \\
3 \\
8 \\
10\end{array}$ & $\begin{array}{l}4 \\
0 \\
2 \\
4 \\
6 \\
4 \\
4 \\
6 \\
3\end{array}$ & $\begin{array}{l}3 \\
1 \\
1 \\
3 \\
4 \\
4 \\
1 \\
4 \\
3\end{array}$ & $\begin{array}{r}15 \\
14 \\
20 \\
12 \\
10 \\
13 \\
13 \\
8 \\
9\end{array}$ & $\begin{array}{l}16 \\
17 \\
19 \\
10 \\
16 \\
15 \\
21 \\
13 \\
12\end{array}$ \\
\hline Total $\ldots$ & . & 60 & 62 & 33 & 24 & 114 & 139 \\
\hline
\end{tabular}

TABLE IV.-Number of Patients Showing Improvement/Detcrioration/No Change in Timed Items and Immediate Recall in the W.A.I.S.

\begin{tabular}{|c|c|c|c|c|c|c|c|c|}
\hline & & \multicolumn{2}{|c|}{ Improved } & \multicolumn{2}{|c|}{ Deteriorated } & \multicolumn{2}{|c|}{$\begin{array}{c}\text { No } \\
\text { Change }\end{array}$} & \multirow{2}{*}{$\begin{array}{c}\begin{array}{c}\text { Difference } \\
\text { in Mean } \\
\text { Change }\end{array} \\
\text { F.A. - P. }\end{array}$} \\
\hline & & F.A. & P. & F.A. & P. & F.A. & P. & \\
\hline $\begin{array}{l}\text { Digit span } \\
\text { Digit Symbol } \\
\text { Block Design } \\
\text { Picture arrangement } \\
\text { Obiect assembly.. }\end{array}$ & $\begin{array}{l}\ldots \\
\cdots \\
\cdots \\
\cdots\end{array}$ & $\begin{array}{r}10 \\
8 \\
5 \\
8 \\
14\end{array}$ & $\begin{array}{r}11 \\
8 \\
11 \\
10 \\
12\end{array}$ & $\begin{array}{l}6 \\
9 \\
8 \\
7 \\
6\end{array}$ & $\begin{array}{l}5 \\
7 \\
6 \\
6 \\
7\end{array}$ & $\begin{array}{r}7 \\
6 \\
10 \\
8 \\
3\end{array}$ & $\begin{array}{l}9 \\
9 \\
9 \\
8 \\
9 \\
6\end{array}$ & $\begin{array}{r}0.12 \\
0.02 \\
-0.27 \\
-0.28 \\
-0.07\end{array}$ \\
\hline
\end{tabular}

F.A. $=$ Folic-acid-treated patients. P. = Placebo-treated patients.

difference is significant $(t=2.8, P<0.05)$. The changes in the extraversion and lie scales are not significant. The evaluation of changes in the behaviour rating scale presented some difficulty as only one control observation was available for each patient. This was compared with the observation made at the end of 26 weeks after starting the treatment. The number of patients showing an improvement/deterioration/no change in each of the nine items rated is shown in Table $V$. There are no significant differences in these changes.

\section{Discussion}

The primary object of the present investigation was to follow up a clinical impression that the administration of folic acid to folate-deficient epileptic patients made no significant difference to the frequency of seizures in the majority. Reynolds (1967), in an uncontrolled study, reported results in 26 chronic epileptic patients. Five were living sheltered lives and 21 were in normal occupations. Folic acid was given orally $5 \mathrm{mg}$. three times a day for from one to three years. In $13(50 \%)$ of these patients the frequency and/or severity of seizures was increased, necessitating cessation of treatment in nine. In six of these nine it was after five months' treatment (range 10 days to 22 months). In one patient status epilepticus was precipitated after 10 months. In only one patient was there an improvement in the frequency of seizures, the remaining 12 patients showing no change. In addition to these changes in seizure frequency, 22 patients showed a definite improvement in mental state (11 of them "very notable") in the form of increased personal drive and initiative, speed of cerebration in thought, speech, and action, alertness, selfconfidence, and sociability. Most showed improvement within three months of starting treatment.

In our folic acid-treated patients, 10 out of $23(43.5 \%)$ showed an increase in frequency of grand mal attacks during the first 26 weeks of treatment, but $11(47.8 \%)$ showed a decrease. Two patients $(8.7 \%)$ showed no change. Though the number showing an increase in fits was less in the placebo-treated group $(5 / 25)$, the difference is not statistically significant, and when the degree of change is taken into account the differences between the folic acid and placebo groups are even smaller $(t=0.05, \mathrm{P}>1.0)$. Reynolds (1967, 1968) pointed out that in six of his nine patients in whom folic acid had to be stopped this action was taken five months or more after starting treatment. It might therefore be said that our period of treatment was too short, but in the 41 patients whom we have now observed for at least one year there is still no difference in the fit frequency in the two groups. The general tendency throughout the trial was for fit frequency to decrease, especially during the period 27-52 weeks after starting treatment, the mean change in grand mal attacks in the folic acid group being -3.75 and in the placebo group -7.0. We did not consider it necessary to alter anticonvulsant treatment in any of the patients.

Since our trial began Ralston et al. (1970) reported a dou- 
ble-blind trial in 27 patients with epilepsy whose serum folate levels were below $3 \mathrm{ng} . / \mathrm{ml}$. The duration of the trial was only three months, and is thus not really comparable to Reynolds's original study; nevertheless, no significant changes in fit frequency were seen.

There was, as expected, no change in the "general" level of intelligence. Neither was there any effect on the timed items of the Wechsler adult intelligence scale or the 15-minute score on Raven's standard progressive matrices, most of the changes being close to zero. This contrasts with the findings of Reynolds $(1967,1968)$ that 22 out of 26 patients showed improvement in "drive," speed of thought and action, alertness, and concentration. In the random letters test, in which speed of thought and action was important, the placebotreated group were on average faster than the folic-acidtreated group, though the difference is not quite significant.

We can find no evidence that folic acid has altered the behaviour or personality of our patients as a group, and though there is a difference $(P<0.05)$ in the mean changes on the neuroticism scale of the Eysenck-Withers personality inventory it is the placebo group which improved slightly. We can suggest no reason for this difference. None of the patients in either group complained of the gastrointestinal and sleep disturbances, malaise, vivid dreaming, and excitability reported by Hunter et al. (1970) in the 14 normal volunteers given folic acid $15 \mathrm{mg}$. daily. Most patients showed no change in the behaviour rating scale; changes which occurred were equally distributed between the two groups (Table V). There was a tendency for the ratings for aggression (item 8) and anger (item 9) to show a higher proportion of improvements at the end of 26 weeks' treatment, but there was no difference between the two groups.

We originally intended to include the patients' subjective assessment of their progress, but this was abandoned. Almost without exception patients in both groups claimed "considerable" improvement in their general condition and most claimed a reduction in fit frequency despite documented evidence to the contrary. Two patients, however, were particularly insistent that they had derived great benefit.

Case 7.-A 21-year-old woman had had centrencephalic epilepsy since the age of 8 and was taking folic acid tablets. During the control period she had 39 grand mal, 3 modified grand mal, and 140 akinetic attacks. During the first 26 weeks on folic acid the seizures were reduced to two modified grand mal and 58 akinetic attacks. There was a further reduction to 37 akinetic attacks during the period 27-52 weeks, but she was observed to have 52 psychomotor attacks; she had had these before entering the trial. Anticonvulsant treatment was not altered. There was no significant change in full scale I.Q. $(83,88)$ nor in the subtest scores, but there was a significant increase from 18 to 31 in the 15minute score on Raven's matrices, the total score being unaffected $(28,32)$. The patient insisted that she was "able to think much more quickly, do things quicker; I feel more lively and with it." The only other value to change significantly was an increase in the neuroticism score on the Eysenck-Withers personality inventory from 9 to 19 .

Case 30.-A 26-year-old woman had had epilepsy due to a rather indefinite right temporal focus since the age of 3. She was on placebo and showed a reduction of grand mal attacks from 64 to 13 and psychomotor attacks from 42 to 3 during the first 26 weeks. There were no significant changes in any of the other values, but she insisted that she was greatly improved, using almost identical phrases as Case 7.

Results confirm our impression that the administration of folic acid has little or no effect on fit frequency, speed of thought and action, personality, or behaviour, except perhaps in isolated cases. Though changes occurred they did so in both directions and to an equal extent in both groups. This is in line with our experience generally that epilepsy is a condition profoundly affected by psychological factors. These conclusions can, of course, be applied only to our populationthat is, people whose epilepsy, and related problems, are of sufficient severity to require admission to an institution-but we must emphasize that less than half $(47 \%)$ of the patients in the trial were regarded as permanent residents. Twentyfour per cent. were patients all likely to return to the community after 18 months' treatment, the remainder requiring somewhat longer.

We thank our nursing staff, who co-operated with all the necessary record-keeping; our secretaries, Mrs. Valerie Bradley and Mrs. Betty Davey, who showed great patience; and Mr. Colin Clark, of I.C.I. Pharmaceuticals Division, for statistical advice. Dr. G. Stores and Mrs. Shelagh Whittaker gave invaluable help and advice on psychological tests. Dr. C. A. K. Bird kindly carried out all biochemical and haematological investigations. Dr. Alan Galbraith, of Geigy Pharmaceuticals Ltd., kindly supplied the folic acid and placebo tablets.

The work was supported by a grant from the British Epilepsy Association

REFERENCES

Chanarin, I., Laidlaw, J., Loughridge, L. W., and Mollin, D. L. (1960). British Medical fournal, 1, 1099

Dennis, J., and Taylor, D. C. (1969). British Medical fournal, 4, 807.

Gordon, N. (1968). Developmental Medicine and Child Neurology, 10, 497.

Hoff brand, A. V., and Necheles, T. F. (1968). Lancet, 2, 528

Hunter, R., Barnes, J., Oakeley, H. F., and Matthews, D. M. (1970). Lancet, 1,61 .

Klipstein, F. A. (1964). Blood, 23, 68

Lanzkowsky, P., Erlandson, M. E., and Bezan, A. I. (1969). Blood, 34, 452

Pritchard, M. (1963). British fournal of Psychiatry, 109, 572.

Ralston, A. J., Snaith, R. P., and Hinley, J. B. (1970). Lancet, 1, 867.

Reynolds, E. H. (1967). Lancet, 1, 1086.

Reynolds, E. H. (1968). Brain, 91, 197.

Reynolds, E. H. (1970). In Modern Trends in Neurology, ed. D. Williams, Vol. 5, p. 271. London, Butterworths.

Reynolds, E. H., Chanarin, I., Milner, G., and Matthews, D. M. (1966a). Epilepsia, 7, 261.

Reynolds, E. H., Milner, G., Matthews, D. M., and Chanarin, I. (1966b) Quarterly fournal of Medicine, 35, 521

Rosenberg, I. H., Godwin, H. A., Streiff, R. R., and Castle, W. B. (1968) Lancet, $2,530$.

Stensrud, P. A., and Palmer, H. (1964). Epilepsia, 5, 364.

Wells, D. G. (1968). Lancet, 1, 146.

Williams, M. (1968). British fournal of Social and Clinical Psychology, 7, 19. 